ROCZNIKI FILOZOFICZNE

Tom LXVII, numer $1-2019$

DOI: http://dx.doi.org/10.18290/rf.2019.67.1-2

MONIKA KOMSTA

\title{
CZY BÓG ZNA ZŁO? \\ ANTYCZNE ROZWIĄZANIE PROBLEMU NA PRZYKŁADZIE FILOZOFII TEMISTIUSZA
}

Boska wiedza (sposób Boskiego poznawania, jak i jego przedmiot) była dla filozofii greckiej tematem raczej marginalnym, choć pewne aspekty tego zagadnienia na przestrzeni wieków starano się przedstawić i wyjaśnić. Pytano najpierw o to, czy Bóg w ogóle poznaje, a zatem czy jest intelektem. Na tak postawione zagadnienie Plotyn odpowiedział, że Jedno-Absolut, będąc pełnią jedności, musi znajdować się ponad podziałem na podmiot poznający i przedmiot poznania, a zatem nie może poznawać. Jedno nie jest bowiem intelektem, ale czymś do intelektu niesprowadzalnym ${ }^{1}$. Jeśli jednak pojmowano Boga jako intelekt (jak w arystotelizmie), to pojawiał się problem sposobu Boskiego poznawania i jego przedmiotu. Arystoteles bowiem tak enigmatycznie przedstawił to zagadnienie, że do tej pory wśród interpretatorów nie ma zgody co do tego, czy Bóg zna świat, czy może tylko samego siebie $^{2}$. Trzeba zauważyć, że greckie pojmowanie doskonałości Boga nie obejmowało wszechwiedzy, a nawet przeciwnie — wszechwiedzę z niej wykluczało. Nowe rozumienie Boskiego poznania i wszechwiedzy wkracza wraz z chrześcijaństwem i zupełnie nową koncepcją Pierwszego Bytu. Jak ściśle dla myślicieli średniowiecznych wszechwiedza wiązała się z Bożą Istotą, może pokazać przykład z Summy teologii, gdzie w artykule 10 kwestii 14 Tomasz z Akwinu zadaje pytanie, czy Bóg poznaje zło. Zarzut pierwszy, w którym przytoczona została wypowiedź Arystotelesa z $O d u s z y^{3}$, a następ-

Dr hab. MoniKa Komsta - Katedra Historii Filozofii Starożytnej i Średniowiecznej, Katolicki Uniwersytet Lubelski Jana Pawła II; adres do korespondencji: Al. Racławickie 14, 20-950 Lublin; e-mail: monika.komsta@kul.pl. ORCID: https://orcid.org/0000-0003-3070-3279.

${ }^{1}$ PLOTYN, Enneady, 5.6.2.

${ }^{2}$ Arystoteles, Metafizyka, 1072b18-21. Zob. Berti 2016, 146; Brunschwig 2000, 288-296.

${ }^{3}$ Summa teologii, I, 14, 10: „Filozof w III księdze $O$ duszy twierdzi, że intelekt, który jest 
nie odpowiedź na ten zarzut ukazują w pewien sposób starcie dwóch tradycji filozoficznych: starożytnej (greckiej) i średniowiecznej. Z jednej strony widoczne jest chrześcijańskie przekonanie o Bożej wszechwiedzy: Bóg jako wszechwiedzący musi znać nie tylko dobro, ale i zło ${ }^{4}$, stąd Tomasz, wyjaśniając wypowiedź Stagiryty, przedstawia go jako zwolennika właśnie takiego stanowiska. Arystoteles jednak nie pojmował Pierwszego Intelektu jako wszechwiedzącego, greckie rozumienie Boskiej doskonałości stało bowiem w sprzeczności z chrześcijańskim pojęciem Boskiej wszechwiedzy.

Wraz z rozwojem filozoficznej koncepcji bóstwa oraz wraz z wpływem rodzącej się myśli chrześcijańskiej w myśli greckiej pojawia się zagadnienie Boskiej wszechwiedzy, a więc również Boskiego poznania zła. Myślicielem, który zadał pytanie o możliwość takiego poznania, był Temistiusz, a ponieważ już samo podjęcie takiego zagadnienia na gruncie filozofii greckiej może wzbudzić u badacza zrozumiałe zainteresowanie, proponuję przyjrzeć się rozważaniom tego myśliciela, który wydaje się skupiać w swojej twórczości wszystko to, co charakterystyczne dla myśli antycznej, a równocześnie wydaje się świadomym nowych rozwiązań zaproponowanych przez chrześcijaństwo. Temistiusz bowiem, włączając do swojej nauki nowe wątki, które mogłyby zrewolucjonizować dotychczasowe rozważania, wraca jednak wciąż do powtarzania tego, co w jakiś sposób grecką myśl ograniczało - na przykładzie jego doktryny bardzo wyraźnie można dostrzec zarówno możliwości rozwoju filozofii greckiej, jak i jej nieprzekraczalne granice.

Temistiusz (ok. 317-388) wyrósł z nurtu arystotelesowskiego, przynależność do niego przekazał mu niejako w spadku ojciec — Eugeniusz, który był miłośnikiem filozofii Arystotelesa. Temistiusz znał jednak dobrze całą filozofię grecką, co dawało jego myśli bardzo szeroką perspektywę i możliwość zaczerpnięcia inspiracji z wielu źródeł, ale również odniesienia się do wielu stanowisk. Wśród jego perypatetyckich poprzedników należy wymienić Aleksandra z Afrodyzji (II/III wiek), którego komentarze wywarły ogromny wpływ na parafrazy Temistiusza, podobnie zresztą jak na całą tradycję komentatorską. Czas, w którym żył Temistiusz, był jednak okresem dominacji filozofii platońskiej. I ją również dobrze znał, a nawet uległ jej wpływowi, choć w ograniczonym zakresie 5 . Trzeba też wspomnieć chrześcijaństwo,

w możności, nie poznaje braku”. A dalej Tomasz odpowiada na ten zarzut: „[...] wypowiedź Filozofa trzeba rozumieć w ten sposób, że intelekt, który nie jest w możności, nie poznaje braku przez brak tkwiący w nim". Tłum. za: ToMASz z AKwINU 1999.

${ }^{4}$ Summa teologii, I,14,1: „[...] w Bogu wszelka wiedza jest w sposób najdoskonalszy”. Tłum. za: Tomasz z AKwINU 1999.

${ }^{5}$ Zob. Komsta 2016, 252-268. 
które z pewnością było mu znane, choć sam chrześcijaninem nie był badacze wskazują na przykład na pewne aluzje znajdujące się szczególnie w mowach Temistiusza, dowodzące znajomości Pisma Świętego ${ }^{6}$. Ten kontekst wpływów trzeba brać pod uwagę, gdy rozważa się doktrynę tego myśliciela. Temistiusz tworzy w okresie schyłkowym filozofii greckiej, gdy wszystko, co ważne, zostało już powiedziane, a rozpoczął się okres komentatorów, wyjaśniających naukę dawnych mistrzów. Żyje więc niejako między ścierającymi się kulturami, wśród chrześcijan, ale wciąż zakorzeniony głęboko $\mathrm{w}$ hellenizmie. Ta perspektywa, jak się wydaje, ukazała mu nowe problemy, na które próbował znaleźć odpowiedź w tradycji filozofii greckiej. Jednym z nich jest pytanie: czy Bóg zna zło?

Problem, który można zrekonstruować na podstawie tekstów Temistiusza, składa się z dwóch zazębiających się ze sobą zagadnień: 1) koncepcji Boga, a dokładnie Boskiego poznania; 2) istoty zła. Znalezienie odpowiedzi na pytanie o sposób, w jaki Bóg poznaje, i o to, co jest (i co może być) przedmiotem Jego poznania, łączy się również z pytaniem o samą istotę Boga, a właściwie zakłada odpowiedź na to pytanie. W starożytnej analizie poznania ważny jest bowiem przede wszystkim ontyczny status podmiotu i przedmiotu poznania, a następnie ich wzajemna relacja, która jest właśnie poznaniem. Należy zatem zapytać zarówno o istotę Bytu Pierwszego, jak i o istotę zła, aby móc odpowiedzieć na postawione w tytule pytanie. Rozpocznę od tego drugiego zagadnienia: czym jest zło według Temistiusza? ${ }^{7}$

Problem zła był obecny i rozważany w myśli greckiej w dwóch aspektach: jako zło w sensie ontycznym i jako zło w sensie moralnym. Dominował jednak aspekt moralny, w którym zło zarówno uczynione, jak i doznane (cierpienie) ostatecznie jawiło się jako pewien błąd poznawczy dotyczący natury rzeczywistości. Jest to pomyłka możliwa do usunięcia, wystarczy bowiem naprawić sąd o rzeczywistości, zrozumieć, jaka naprawdę jest, co jest jej istotą, a wtedy sama ta wiedza zmieni nasze postępowanie - tradycję tę zapoczątkował Sokrates, a kontynuowali kolejni myśliciele do Sokratesa nawiązujący.

Natomiast zło w sensie ontycznym Platon wiązał z materią, która jest wieczna, istnieje niezależnie od świata idei i od Demiurga. Jest źródłem pewnego nieporządku w świecie, wielości, chaosu, który może być naprawiony przez odzwierciedlenie w nim idei. Arystoteles nie podzielał stanowiska swego mistrza, ale też nie poświęcił zbyt wiele uwagi naturze zła,

\footnotetext{
${ }^{6}$ Zob. STERTZ 1976, 353; DownEY 1957, 261-263.

${ }^{7}$ Temu zagadnieniu poświęcony jest artykuł GuLDENTOPs 2001.
} 
a jego rolę w świecie raczej marginalizowat ${ }^{8}$, podkreślając regularność i uporządkowanie wszechświata. Zło wiązało się z możnością, która istniejąc w bytach materialnych, jest skierowana do przeciwieństw: dobra i zła. Coś może stać się dobre albo złe, wciąż jednak możność sama w sobie jest dobra, ponieważ w pierwszym rzędzie jest zwrócona ku dobru' ${ }^{9}$ Jego naukę twórczo rozwija Aleksander z Afrodyzji, który w cytacie przytoczonym przez Symplicjusza mówi:

On [brak] jest również przyczyną zła. Nawet jeśli materia jest uważana za przyczynę złych rzeczy, to dlatego, że z powodu braku nie może przyjąc uporządkowania wiecznych bytów ${ }^{10}$.

Zło nie jest wywołane samą obecnością materii w świecie, a więc materia sama w sobie nie jest przyczyną ontycznego zła. Zło związane jest $\mathrm{z}$ brakiem formy, której materia jest pozbawiona, a także $z$ brakiem tej doskonalszej formy, której nie może przyjąć. Połączenie hylemorficzne wymaga bowiem spełnienia pewnych wstępnych warunków zarówno przez formę, jak i przez materię - nie łączą się one ze sobą dowolny ${ }^{11}$. Aleksander nawiązuje do teorii zmiany, do której obok materii i formy potrzebny jest również brak, i łączy z przekonaniem o hierarchicznym uporządkowaniu rzeczywistości, w której doskonalszymi są byty niematerialne. Tam, gdzie w świecie jest obecna możność, jest także zmiana, a więc i brak. Im doskonalsze byty, tym mniej możności, a więc i zmiany, a więc i mniej braku. Temistiusz w swoich rozważaniach o ciałach niebieskich, a więc o najdoskonalszych bytach materialnych, podkreśla, że choć posiadają one możność, zdolność do zmiany, to jednak w ograniczonym zakresie, podlegają bowiem tylko zmianie miejsca ${ }^{12}$. $\mathrm{Z}$ tego też względu są najdoskonalszymi bytami materialnymi. Ze zmiany wyłączone są tylko byty będące czystymi formami, czyli czystymi aktami. Są one w ten sposób bytami pozbawionymi ontycznego zła, a więc w pełni dobrymi. Takim bytem jest w pierwszym rzędzie Pierwsza Przyczyna.

W ten sposób w tradycji perypatetyckiej można odnaleźć źródła stanowiska Temistiusza. Badacz tego zagadnienia, Guy Guldentops, uważa właśnie Aleksandra, którego komentarze Temistiusz z pewnością znał, za źródło

\footnotetext{
${ }^{8}$ Zob. GULDENTOPS 2001, 208.

${ }^{9}$ Zob. Arystoteles, Metafizyka, 1051a15-21.

${ }^{10}$ Symplicjusz, In Aristotelis Physicorum libros quattuor commentaria, 249, 12-14. (Jeśli nie zaznaczono inaczej, thumaczenia są moje - M.K.).

${ }^{11}$ Zob. AleKSANDER Z AFrodyZJI, O duszy, 8,13-25.

${ }^{12}$ Zob. Temistiusz, In Metaphysicam, 5, 9-15.
} 
Temistiuszowej koncepcji zła ${ }^{13}$. Aleksander był bowiem poprzednikiem Temistiusza zarówno jako perypatetyk, jak i jako komentator Arystotelesa ${ }^{14}$. Powstaje jednak pytanie, czy należy źródła tej koncepcji ograniczyć tylko do arystotelizmu, wydaje się bowiem, że nie tylko Aleksander mógł być inspiracją dla rozwiązania tego zagadnienia. $Z$ uwagi na liczne elementy neoplatońskie, które pojawiają się przede wszystkim w mowach Temistiusza, ale także parafrazach, można podejrzewać, że duże znaczenie mogła mieć nauka Plotyna, który również zdefiniował zło jako brak dobra ${ }^{15}$. Materia w filozofii neoplatońskiej jest ujmowana jako źródło zła nie dlatego, że w sensie ontycznym jest zła, jest bowiem pośrednim tworem Jednego i jako taka nie może być zła. Materia jako kraniec mocy twórczej Jednego jest złem, ale złem jedynie $\mathrm{w}$ sensie braku dobra ${ }^{16}$. Trzeba zauważyć, że u Plotyna ta koncepcja zła ma szersze znaczenie niż $\mathrm{w}$ doktrynie perypatetyckiej (Aleksander z Afrodyzji), wiąże się bowiem z koncepcją Jednego stwarzającego świat nie z zastanego wcześniej tworzywa, które swoją chaotyczną istotą powoduje, że to, co z niego powstaje, jest obarczone niedoskonałością i jest złe. Jedno jest źródłem wszystkich bytów i jest źródłem tylko dobra — ta myśl będzie się pojawiać w mowach Temistiusza. Zwracam na to uwagę, ponieważ w pismach Temistiusza znajdują się wątki, które trudno wytłumaczyć prostą kontynuacją tradycji perypatetyckiej, mają natomiast, podkreślany przez niektórych badaczy, charakter platoński ${ }^{17}$. Aby adekwatnie opisać i zinterpretować stanowisko Temistiusza, należy te elementy platońskie odnaleźć i ocenić skalę ich oddziaływania. Czy powodują one przekształcenie systemu perypatetyckiego w jego podstawach, tzn. czy Temistiusz na tyle koryguje dotychczasową tradycję arystotelesowską, żeby nowe wątki nie stanowiły tylko rzucającego się w oczy, niezbyt dopasowanego dodatku, ale wraz ze starymi elementami jedną całość? Wyraźnym śladem wpływu filozofii neoplatońskiej byłoby przyjęcie jakiejś formy plotyńskiej koncepcji powstawania świata, z którą wiąże się odrzucenie możliwości pojmowania Boga jako

\footnotetext{
${ }^{13}$ Zob. GulDENTOPS 2001, 190-191.

${ }^{14}$ Aleksander był ważny dla całej tradycji komentatorskiej, która z jednej strony korzystała z jednych rozwiązań, z drugiej zaś krytykowała inne. Podobnie Temistiusz - zob. KomstA 2016, 68-69.

${ }^{15}$ Temistiusz najprawdopodobniej znał Enneady, a z pewnością był zaznajomiony z twórczością Porfiriusza i Jamblicha. Zob. KuPREEVA 2010, 403; VANDERSPOEL 1995, 26.

${ }^{16}$ Plotyn, Enneady, I, 8, 3, 12-20.

${ }^{17}$ Wpływ platonizmu szczególnie zaznacza się w mowach Temistiusza — zob. THEMISTIUS 2001, 2. Autorzy wstępu wskazują np. na mowę V, gdzie można odnaleźć neoplatoński motyw relacji między Jednym a światem od Niego pochodzącym.
} 
źródła zła w świecie. Czy zatem można wyśledzić tego rodzaju zmianę w pojmowaniu świata i jego zależności od Boga?

Chciałabym jednak najpierw wskazać na fragmenty wypowiedzi Temistiusza, które są kontynuacją myśli Aleksandra z Afrodyzji, a więc tradycji perypatetyckiej. W parafrazie Fizyki Arystotelesa mówi:

Zło [złe rzeczy] powstaje z braku i przez niego. Materia bowiem, ponieważ jest zdolna do przyjęcia braku i ma [go] w możności, jest zbyt słaba, aby stale utrzymywać formy, które przyjmuje ${ }^{18}$.

W podobny sposób stwierdza w parafrazie księgi XII Metafizyki:

Czy [Anaksagoras] powie, że zło pochodzi z ułomności materii i zawartego wewnątrz niej braku, jak my powiedzieliśmy? ${ }^{19}$

Temistiusz powtarza tu wyraźnie słowa Aleksandra z Afrodyzji mieszczące się w tradycji Arystotelesa i można by na tym poprzestać, gdyby nie inne fragmenty jego pism, szczególnie te pochodzące z mów, które przedstawiają zagadnienie zła i jego źródła w szerszym kontekście. W Mowie VI Temisitusz krytykuje Homerycki obraz Boga, który jest dawcą i dobra, i zła ${ }^{20}$. Bóg - Zeus - nie jest twórcą zła, a jedynie dobra, zło natomiast pochodzi $\mathrm{z}$ wyboru dokonywanego przez człowieka.

Homer jednak, jak się wydaje, niewłaściwie to przedstawił, gdy umieścił w domu Zeusa dwa dzbany wypełnione przeznaczonymi losami, jeden dobrymi, drugi przeciwnymi. W niebie nie ma bowiem magazynu złych losów, a ten drugi dzban został uformowany z mułu pochodzącego od nas i ziemi, i to my napełniamy go i opróżniamy ${ }^{21}$.

To odniesienie problemu zła do Boga, który nie jest jego twórcą, mogłoby otworzyć zupełnie nową płaszczyznę rozważań wraz z pytaniem, czy Bóg w ogóle jest twórcą świata. Temistiusz twierdzi bowiem bardzo wyraźnie, podobnie jak Plotyn, że ontycznym źródłem zła nie jest Pierwsza Przyczyna. Czy Bóg, który jest jedynie przyczyną celową świata, przyczyną ruchu pierwszej sfery niebieskiej, może być w ogóle brany pod uwagę jako przyczyna sprawcza zła? Niewątpliwie przytoczony wyżej cytat może wskazać na takie

\footnotetext{
${ }^{18}$ Temistiusz, In Physicam, 33, 6-8.

${ }_{19}$ Temistiusz, In Metaphysicam, 37, 3-5.

${ }^{20}$ Guldentops 2001, 197.

${ }^{21}$ Temistiusz, Oratio, VI, 79c.
} 
przekształcenie doktryny perypatetyckiej, które dokonałoby radykalnego zwrotu w metafizyce arystotelesowskiej na wzór metafizyki neoplatońskiej. Chciałabym wskazać na kilka innych fragmentów, które mogą rodzić podobne wątpliwości co do spójności z tradycją perypatetycką. W parafrazie księgi XII Metafizyki pojawia się obraz Boga, który jest źródłem porządku w świecie, a więc również dobra.

Jeśli jednak Bóg myśli, że jest formą wszystkiego, to on sam jest także zasadą prawidłowości bytów i ich porządku i bez wątpienia równocześnie pojmuje, że on sam jest zasadą ich prawidłowości i porządku ${ }^{22}$.

Arystoteles nie pojmował Pierwszej Przyczyny jako formy wszystkiego ${ }^{23}$, taka myśl nie pojawia się też u Aleksandra z Afrodyzji. Temistiusz, choć nie udziela wprost odpowiedzi na pytanie, co to znaczy, że Bóg jest zasadą i formą wszystkich bytów, to łączy Boskie bycie formą wszystkiego z Jego samopoznaniem i poznaniem całości rzeczywistości. Bóg celowo porządkujący świat jest dla Temistiusza źródłem porządku i prawidłowości w świecie, który pragnie tę doskonałość Pierwszego Poruszyciela naśladować. Świat uporządkowany hierarchicznie w odpowiedni dla siebie sposób stara się odzwierciedlać prawo, którym jest sama Pierwsza Przyczyna. Te rozważania Temistiusza można odczytać jako interpretację rozdziału 10 księgi XII Metafizyki i słów Arystotelesa o porządku hierarchicznym panującym w świecie, w tym względzie nie wykraczałby poza doktrynę Arystotelesa, gdyby nie słowa, które padają pod koniec tej parafrazy:

Bóg rzeczywiście ukończył i udoskonalił świat, lecz ustanowił ciągłe powstawanie, aby materia postępowała za Pierwszą Przyczyną. Na podstawie tego usuwa się nie tylko mniemanie zakładających, że jest wiele zasad cielesnych albo że Bóg i materia są zasadami, lecz także przyjmujących, że formy są jakby zasadami rzeczy, ponieważ trzeba, żeby także do form była zastosowana inna wspanialsza zasada, przez którą są tworzone i która łączyły pojedyncze między sobą wraz z bytami powstającymi i ginącymi ${ }^{24}$.

Przypisywanie Bogu bycia zasadą porządku hierarchicznego rzeczywistości wraz ze słowami o 'ukończeniu' czy 'wykończeniu' świata i twierdzeniem o tworzeniu form, kierują uwagę w stronę zupełnie innego obrazu świata niż ten, który wyłania się z filozofii Stagiryty. Można bowiem zadać

\footnotetext{
${ }^{22}$ Temistiusz, In Metaphysicam, 34, 19-22.

${ }^{23}$ Zob. BERTI 2016, 107.

${ }^{24}$ Temistiusz, In Metaphysicam, 38, 7-14 .
} 
sobie pytanie, czy wystarczającym uzasadnieniem tych słów jest koncepcja Pierwszej Przyczyny, która jest jedynie przyczyną celową świata. Te wątpliwości pojawiają się kilkakrotnie podczas lektury parafrazy księgi XII Metafizyki, ale przytoczę tylko fragment najbardziej wyrazisty. W parafrazie rozdziału 3 Temistiusz po oddaleniu platońskiego poglądu o formach, które istnieją w sposób samodzielny poza materią, przedstawia jednak trudność wywołaną powstawaniem spontanicznym. Jeśli przyczynami powstawania poszczególnych rzeczy są indywidualne immanentne formy, to jak wythumaczyć to, że pewne prymitywne zwierzęta, jak żaby i pszczoły, nie powstają $\mathrm{z}$ osobników o tej samej formie. Aby to wyjaśnić, Temistiusz wskazuje, że formy i proporcje są ukryte w samej naturze świata i to one są odpowiedzialne za powstawanie spontaniczne. A jednak pewną wątpliwość pozostaje:

I nie należy się dziwić, że natura, nie znając tego, co czyni, osiąga zamierzony cel, a sama ani nie poznaje tego, co robi, ani nie postrzega tego w akcie. I to wskazuje, że tamte proporcje są sprowadzane przez moc godniejszej i szlachetniejszej przyczyny, umieszczonej na wyższym stopniu hierarchii niż jest ona sama [natura] ${ }^{25}$.

Kolejny raz pojawia się wizja, co prawda dość niejasna, tworzenia świata przez Boga. Słowa Temistiusz mogą wywołać zdziwienie i odczytanie odbiegające od paradygmatu arystotelesowskiego, czego przykład podaje Inna Kupreeva. Komentując powyższy fragment, przywołuje interpretację dokonaną przez Awerroesa. Komentator rozumiał bowiem ten tekst jako wyraz Awicenniańskiej koncepcji Dator Formarum — inteligencji formującej rzeczywistość i umieścił w kontekście stwarzania świata. Kupreeva sądzi jednak, że brak wystarczającego uzasadnienia dla takiego rozumienia przywołanego wyżej tekstu, ponieważ wciąż da się go odczytać w ramach zakreślonych przez arystotelizm. Formy i proporcje, które są przyczynami spontanicznego powstawania istot żywych, ukryte w naturze tak, że są dla nas niezauważalne, są naturalną, immanentną przyczyną tego typu powstawania. Badaczka przyznaje jednak, że Temistiusz $\mathrm{w}$ tym miejscu jest nieprecyzyjny ${ }^{26}$. I na tym chyba polega cały problem. Temistiusz używa czasami języka obcego dla arystotelizmu, przez co można odnieść wrażenie, że wprowadza jakieś nowe elementy do starej koncepcji ${ }^{27}$. Robi to jednak jedynie w warstwie

\footnotetext{
${ }^{25}$ Temistiusz, In Metaphysicam, 9, 31-35.

${ }^{26}$ Zob. KuPREEVA 2010, 412.

${ }^{27}$ Guy Guldentops $(2001,190)$ podaje przykłady terminów greckich: $\mu \varepsilon \tau \alpha \lambda \alpha \mu \beta \alpha ́ v \varepsilon ı v$ [meta-

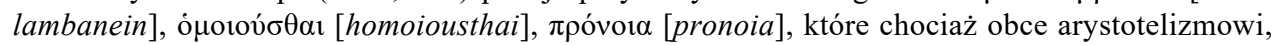
to w pismach Temistiusza nie powodują żadnej widocznej zmiany doktryny.
} 
słownej, a ponieważ nie następuje za tym przebudowa całego systemu, pozostaje uznanie tego fragmentu $i$ innych podobnych za przejaw mało precyzyjnego języka. Trzeba też zwrócić uwagę, że przytoczone wyżej fragmenty pochodzą z tekstu (parafrazy ksiegi XII Metafizyki), który został nam przekazany w wersji znacznie oddalonej od oryginału. Grecka wersja tekstu zaginęła, pozostały tylko dwa tłumaczenia XIII-wieczne hebrajskie (przekład $\mathrm{z}$ arabskiego tłumaczenia greckiego oryginału) i renesansowe łacińskie. Prześledzenie zależności terminologicznych jest tu wysoce utrudnione, jeśli nie niemożliwe. Pozostaje stwierdzić, że żadnym miejscu parafrazy ks. XII Metafizyki Temistiusz nie rozwija wątku tworzenia świata przez Boga na tyle jasno, że można by powiedzieć, iż zrywa z arystotelizmem, a czerpie inspirację z neoplatonizmu. Byłoby to raczej niemożliwe, ponieważ broni Arystotelesowskiego przekonania o wieczności świata ${ }^{28}$. Nie jest to więc charakterystyczne dla Plotyna połączenie koncepcji Jedna z odrzuceniem istnienia ontycznego źródła zła, ale jedynie próba udoskonalenia doktryny perypatetyckiej (w formie rozwiniętej przez Aleksandra z Afrodyzji) tak, aby mogła konkurować z koncepcją platońską, a także z neoplatonizmem chrześcijańskim $^{29}$. Wydaje się, że mają rację ci autorzy, którzy wskazują na możliwość zinterpretowania całości nauczania Temistiusza $\mathrm{w}$ ramach szeroko pojętego arystotelizmu $^{30}$. Tym bardziej że można myśl Temistiusza porównać z pracą, jaką niecałe 200 lat później włożył Jan Filopon w obalenie całości fizyki Arystotelesa (szczególnie koncepcji wiecznego ruchu) po to, aby pokazać, że świat nie jest wieczny, a więc musi mieć swego Stwórcę. Koncepcja zła jako braku i Boga, który nie jest i nie może być jego twórcą, mogłaby być drogą do przekroczenia arystotelizmu. Temistiusz jednak nie zdobywa się na tak radykalny krok, pozostając przy arystotelesowskiej koncepcji wieczności świata. Tym samym wszelkie nowe idee, przede wszystkim Boga twórcy dobra i świata mają charakter zmiany czysto werbalnej.

Znając stanowisko Temistiusza w kwestii istoty zła, można przejść do koncepcji Boskiego poznania. Należy jednak dookreślić bliżej istotę Boga,

\footnotetext{
${ }^{28}$ Zob. Temistiusz, In Metaphysicam, 14, 2-15, 28. Powtarza tam argumenty Arystotelesa, że istnieje Pierwszy Nieporuszony Poruszyciel, ponieważ ruch i czas jest wieczny.

${ }^{29}$ Właśnie Aleksander z Afrodyzji pokazał, że można udoskonalić arystotelizm i przystosować do nowych wyzwań, sięgając po pewne narzędzia pojęciowe wypracowane w innych systemach, szczególnie stoickim.

${ }^{30}$ Guy Guldentops $(2001,190)$, rozważając rozumienie zła jako braku i terminologię platońską użytą przez Temistiusza do omówienia tego zagadnienia, zwraca uwagę na jednak arystotelesowski charakter tej koncepcji. Za arystotelesowskim charakterem filozofii Temistiusza argumentuje również Henry J. Blumenthal (1979, 391-400).
} 
ponieważ te wszystkie nowe motywy w koncepcji Boskiego Bytu są u Temistiusza osadzone w arystotelesowskiej doktrynie Pierwszego Intelektu.

W tradycji arystotelesowskiej Bóg jest pojmowany jako najwyższy intelekt, a zarazem byt będący w pełni aktualnością, Pierwszy Poruszyciel świata. Co jest przedmiotem myśli tego najdoskonalszego podmiotu myślenia? W rozdziale 9 księgi XII Metafizyki Arystoteles rozważa kwestię intelektu (Pierwszego Intelektu) i jego przedmiotu ${ }^{31}$. Problem polega na tym, że w tradycji perypatetyckiej poznanie intelektualne rozumiane jest jako utożsamienie się podmiotu i przedmiotu poznania. W przypadku intelektu związanego z materią będzie to jedność tylko chwilowa, ale intelekt niezwiązany $\mathrm{z}$ materią może doskonale utożsamić się ze swoim przedmiotem ${ }^{32}$. Co może zatem poznać Pierwszy Intelekt? Czy może poznać jakikolwiek byt poza sobą? Poznawanie czegokolwiek innego oznaczałoby degradację Najwyższego Bytu, ponieważ wtedy Jego doskonałość pochodziłaby od czegoś poza Nim - przedmiotu poznania. W przypadku Boskiego poznania pozwala to zrozumieć, dlaczego Absolut nie może poznawać bytów niższych od siebie - Jego własna doskonałość nie pozwala na utożsamienie się z bytami niedoskonałymi ${ }^{33}$. Czy to jednak oznacza, że Pierwszy Intelekt nie zna świata i nie wie o jego istnieniu? Czy to możliwe, żeby Bóg poznawał tylko samego siebie? ${ }^{34} \mathrm{~W}$ parafrazie ks. XII Metafizyki Arystotelesa Temistiusz podejmuje ten problem wskazując, że Absolut będąc zasadą świata musi znać to, czego jest racją.

[...] Pierwszy Intelekt poznaje świat. Kiedy bowiem poznaje siebie, poznaje, czym On sam jest, i już poznaje, że jest przyczyną i zasadą rzeczy ${ }^{35}$.

Bóg poznaje siebie i równocześnie właśnie przez to poznaje siebie jako zasadę wszystkiego, dlatego w sposób pośredni poznaje wszystkie byty. Utrzymane zostaje rozumienie poznania intelektualnego jako doskonałego zjednoczenia niematerialnego podmiotu i przedmiotu poznania, ale jednak wiedza Boga zostaje rozciągnięta na całość rzeczywistości, której Bóg jest

\footnotetext{
${ }^{31}$ Nie ma tutaj miejsca na rozważanie zagadnienia, czy Arystoteles mówi w tym rozdziale o intelekcie Boskim czy ludzkim. Zainteresowanych odsyłam do BRUNSCHWIG 2000, 275-306; Kosman 2000, 307-326.

${ }^{32}$ Zagadnienie to omawia również Aleksander z Afrodyzji w swoim traktacie $O$ duszy, 87, 24 $-88,16$.

${ }^{33}$ Temistiusz, In Metaphysicam, 30, 40-42: „Jeśli zaś to, co jest przedmiotem myślenia, jest poza intelektem, a nie w nim samym, to z pewnością będzie od niego znakomitsze i bardziej wyjątkowe, to bowiem jest zasadą i przyczyną, która powoduje, że intelekt myśli".

${ }^{34}$ Jest to problem szeroko dyskutowany wśród badaczy, zob. np. BERTI 2016, s. 146.

35 Temistiusz, In Metaphysicam, 34, 12-15.
} 
przyczyną. Jest to więc koncepcja Boga rozumianego jako intelekt, który może poznawać siebie, ale poznając jedynie siebie, poznaje również świat, a raczej zasady świata, bo - jak mówi Temistiusz w innym miejscu parafrazy — Bóg nie może poznawać jednostkowych bytów:

Oczywiście myślenie o jakichś bytach jednostkowych jest czymś marnym, o wiele bardziej dla tego myślącego, którego forma przewyższa rzecz pomyślaną i który zwykle staje się jednym i tym samym z tym, co jest pomyślane ${ }^{36}$.

Można więc wrócić do pytania zadanego na początku: czy Bóg zna zło? Odpowiedź na nie pada w parafrazie $O$ duszy Arystotelesa.

Jeśli więc pewien intelekt nie ma udziału w możności, nie poznaje też braku, a więc także i zła. Taki jest intelekt przychodzący z zewnątrz, a o wiele bardziej Pierwsza Przyczyna, ponieważ o wiele bardziej jest odsunięta od tego, co w możności. Dlatego ten Intelekt poznaje to, co będąc w najwyższym stopniu, najbardziej jest formą i najbardziej oddalone od braku oraz nieobecności struktury ${ }^{37}$.

Temisitusz nawiązuje w tym miejscu do tradycji perypatetyckiej, rozróżniającej wyraźnie funkcje intelektu czynnego i możnościowego. Za Stagirytą, a może bardziej jeszcze za Aleksandrem z Afrodyzji, który kodyfikuje psychologię perypatetycką, Temistiusz wyróżnia rodzaje czy może raczej poziomy czy stany intelektu ${ }^{38}$, a mając na względzie sposób działania, czyli poznawania, mówi:

Taki jest intelekt w możności, w pewien sposób poznaje przeciwieństwa przez przeciwieństwa, przez to, że jest w akcie, poznaje formy, a przez możność to, co jest związane z brakiem. Możność i aktualność są bowiem w pewien sposób przeciwieństwami ${ }^{39}$.

Intelekt w możności jest intelektem właściwym człowiekowi, dzięki niemu można przeprowadzać rozumowania i poznawać otaczającą nas rzeczywistość świata zmysłowego. Nie jest to intelekt w pełni zaktualizowany, ponieważ ma w sobie możność, dzięki której poznaje przeciwieństwa, w tym także brak. Bóg natomiast, Intelekt będący czystym aktem, zła poznawać nie może. Poznanie zła - braku wiąże się bowiem z poznawaniem przeciwieństw, do czego zdolny jest

\footnotetext{
${ }^{36}$ Temistiusz, In Metaphysicam, 31,11-14 .

${ }^{37}$ Temistiusz, Parafraza 'O duszy' Arystotelesa, 111, 35-112, 3.

${ }^{38}$ Aleksander wyróżnia intelekt materialny, habitualny i czynny, a Temistiusz — bierny, możnościowy i czynny; nie są one dla siebie ścisłymi odpowiednikami.

${ }^{39}$ Temistiusz, Parafraza 'O duszy' Arystotelesa, 111, 31-34.
} 
tylko intelekt, który posiadając w sobie pewną możność, a więc zdolność do poznawania, może zarówno działać, jak i nie działać, poznawać i nie poznawać. Ta ontyczna struktura intelektu niższego pozwala mu na abstrahowanie i poznawanie przez przeciwieństwo, a zatem również na poznanie braku.

W tym właśnie momencie składają się w całość wymienione wcześniej elementy: Bóg jako intelekt poznający tylko siebie, ale siebie, który jest zasadą porządku i doskonałości świata, nie może poznawać tego, co doskonałością nie jest, poznanie oznacza bowiem utożsamienie się z poznawanym przedmiotem. Takie rozumienie poznania wyklucza automatycznie z kręgu przedmiotów możliwych do poznania wszystkie byty poza samym Pierwszym Intelektem, ponieważ są od Niego mniej doskonałe. Bóg poznaje tylko samego siebie i to, że jest zasadą świata. Bóg nie jest jednak twórcą ani zasadą zła, które jest po prostu brakiem dobra, a zatem Bóg poznawać go nie może, ponieważ jest intelektem $\mathrm{w}$ pełni zaktualizowanym. Brak tkwiący w materii wiąże się z bytami jednostkowymi, których Boski Intelekt również nie poznaje. Koncepcja poznania intelektualnego i Boga rozumianego jako intelekt stawia tu poznaniu doskonałego Bytu granicę, której przekroczyć nie można.

Znamienne w kontekście filozofii greckiej jest jednak samo pytanie o możliwość poznania zła. Weźmy najdoskonalszą grecką koncepcję Boga Plotyńską: tam takie pytanie paść w ogóle nie może, ponieważ Jedno nie poznaje. Jak się okazuje, ludzki intelekt jako niedoskonały może poznawać zło, Boski zaś, doskonały - nie. Ale równocześnie nie można zapomnieć o charakterystycznym dla filozofii greckiej schemacie rozumowania, który nie łączy doskonałości Bytu Pierwszego z wszechwiedzą.

Bardziej godny jest bowiem nie ten intelekt, który poznaje więcej, ale ten, który poznaje to, co lepsze ${ }^{40}$.

Aby zrozumieć to stwierdzenie, trzeba jeszcze raz wrócić do tego, jak w tradycji perypatetyckiej rozumiano poznanie intelektualne. Poznanie intelektualne to utożsamienie podmiotu i przedmiotu, w przypadku bytów niematerialnych - utożsamienie doskonałe. Doskonałość intelektu będzie więc zależeć również od poznawanego przezeń przedmiotu. Boski Intelekt jest najdoskonalszy, ponieważ poznaje przedmiot najdoskonalszy — samego siebie. Jego doskonałość nie wiąże się więc w żaden sposób z wszechwiedzą, wiedzą o wszystkim, co istnieje i co nie istnieje — zależy tylko i niemalże wyłącznie od przedmiotu poznania.

\footnotetext{
${ }^{40}$ Temistiusz, Parafraza 'O duszy' Arystotelesa, 112, 10.
} 
Gdy patrzy się na myśl teologiczną starożytnych perypatetyków, których ostatnim przedstawicielem, podsumowującym tradycję szkoły, był Temistiusz, z perspektywy teologii średniowiecznej, to, co zostało przez nich wypracowane, może wydać się niewystarczające, a może nawet rozczarowujące. Te drobne wzmianki, które wydają się zmieniać arystotelesowską naukę o Bogu, okazują się tylko modyfikacjami warstwy słownej doktryny, a nie zmianą rzeczywistą. Kiedy jednak spojrzymy nie na odpowiedzi, ale na zadawane pytania, to trzeba stwierdzić, że Temistiusz, filozof znajdujący się pomiędzy różnymi nurtami i niejako epokami, postawił sobie różne ważne pytania, pytania istotne dla kolejnych pokoleń myślicieli aż do dzisiaj. Czy jego rozwiązania były zadowalające, to już zupełnie inna kwestia. Można przyjąć, że uwzględniając przyjęte przez niego założenia, nie można było odpowiedzieć inaczej. Temistiusz jednakże wykracza poza schemat nakreślony przez Arystotelesa w kwestii obecności Boga w świecie i przedstawia koncepcję naznaczoną neoplatonizmem, neoplatońską koncepcją Jednego źródła wszystkich bytów. Jak już jednak wcześniej zaznaczyłam, wpływy neoplatońskie są dosyć powierzchowne, gdyż nie prowadzą do przemodelowania wizji całości rzeczywistości. Nie da się bowiem pogodzić koncepcji wiecznego ruchu i jego Nieruchomego Poruszyciela z koncepcją Jednego, od którego wszystko pochodzi i które daje początek nie tylko ruchowi, ale bytowaniu wszystkiego. Odpowiedź Temistiusza na pytanie dotyczące Boskiej wszechwiedzy również mieści się $\mathrm{w}$ ramach nakreślonych przez doktrynę perypatetycką czy - szerzej — nawet grecką. Podejście Temistiusza jest bowiem typowe dla paradygmatu greckiego, który zło metafizyczne uważa za coś odwiecznie wpisane w świat i nie przypisuje problemowi wiedzy Boga o złu szczególnego znaczenia. Tym niemniej wydaje się, że samo postawienie pytania o Boską znajomość zła pokazuje nową perspektywę filozofii greckiej, perspektywę inspirowaną chrześcijaństwem. Odpowiedź Temistiusza nie dokonuje jakiegoś przełomu, podobnie jak w kwestii pojmowania istoty zła - być może nie doceniał jeszcze wagi tego zagadnienia i konsekwencji płynących z takiego rozwiązania. Problem ten stanie się naprawdę istotny, gdy chrześcijaństwo przyniesie koncepcję Boga Stwórcy, Boga wszechwiedzącego. 


\section{REFERENCJE}

AleXANDer Aphrodisiensis. 1887. De anima. W: Commentaria in Aristotelem Graeca. Supplementum. Ed. I. Bruns. Supp. 2.1. Berlin: G. Reimer.

Aleksander z Afrodyzi. 2013. $O$ duszy. Przełożyła Monika Komsta. Lublin: Polskie Towarzystwo Tomasza z Akwinu.

Arystotle. 1924. Metaphysics. Ed. W.D. Ross. Vol. 2. Oxford: Clarendon Press.

Berti, Enrico. 2016. Profil Arystotelesa. Przełożył Marian Wesoły. Poznań:Wydawnictwo Naukowe Wydziału Nauk Społecznych Uniwersytetu im. Adama Mickiewicza w Poznaniu.

Blumenthal, Henry J. 1979. Themistius, the Last Peripatetic Commentator on Aristotle?. W: Glen Bowersock (red.). Arktouros, 391-400. Berlin: de Gruyter.

Brunschwig, Jacques. 2000. Metaphysics 1,9: Short-Lived Thought Experiment?. W: Michael Frede i David Charles (eds). Aristotle's Metaphysics Lambda, 275-306. Oxford: Oxford University Press.

Downey, Glanville. 1957. „Themistius and the Defense of Hellenism in the Fourth Century”. The Harvard Theological Review 50: 259-274.

Guldentops, Guy. 2001. „Themistius on Evil”. Phronesis 46: 189-208.

Komsta, Monika. 2016. Temistiusz. Zmierzch psychologii perypatetyckej. Lublin: Wydawnictwo KUL.

Kosman, Aryeh. 2000. Metaphysics 1, 9: Divine Thought. W: Michael Frede i David Charles (eds). Aristotle's Metaphysics Lambda. Oxford: Oxford University Press, s.307-326.

Kupreeva, Inna. 2010. Themistius. W: Lloyd P. Gerson (ed.). The Cambridge History of Philosophy in Late Antiquity. Vol. I. Cambridge: Cambridge University Press, s. 397-416.

Plotinus. 1951. Opera. Ed. Paul Henry i Hans-Rudolf Schwyzer. Vol. 1. Leiden: J.E. Brill.

Plotinus. 1959. Opera. Ed. Paul Henry i Hans-Rudolf Schwyzer. Vol. 2. Leiden: J.E. Brill.

Plotyn. 1959. Enneady. Przełożył Adam Krokiewicz. T.1-2. Warszawa: Państwowe Wydawnictwo Naukowe.

StertZ, Stephen A. 1976. „Themisitus: A Hellenistic Philosopher in the Chrisitian Roman Empire". The Classical Journal 71: 349-358.

SymplicJus.1882. In Aristotelis Physicorum libros quattuor commentaria. W: Commentaria in Aristotelem Graeca. Ed. Hermann Diels. Vol. 9. Berlin: G. Reimer.

Themistius. 1899. In libros Aristotelis De anima paraphrasis. W: Commentaria in Aristotelem Graeca. Vol. V. 1. Ed. R. Heinze. Berlin: G. Reimer.

Themistius. 1900. In Aristotelis Physica paraphrasis. W: Commentaria in Aristotelem Graeca, vol. V. 2. Ed. H.Schenkl. Berlin: G. Reimer.

Themisitius. 1903. In Metaphysicam paraphrasis hebraice et latine. W: Commentaria in Aristotelem Graeca. Vol. V. 5. Ed. S. Landau Berlin: G. Reimer.

Themisitus.1965. Orationes quae supersunt. Ed. H. Schenk1, G. Downey. Leipzig: Teubner.

Themistius. 2001. Politics, Philosophy, and Empire in the Fourth Century. Select Oration of Themistius. Translation and introduction P. Heather, D. Moncur. Liverpool: Liverpool University Press.

Temistiusz. 2016. Parafraza „O duszy” Arystotelesa. Przełożyła Monika Komsta. Lublin: Polskie Towarzystwo Tomasza z Akwinu.

Tomasz z AKwINU. 1999. Traktat o Bogu. Przekład i komentarze Gabriela Kurylewicz, Zbigniew Nerczuk i Mikołaj Olszewski. Kraków: Znak.

VANDERSPOEL, John. 1995. Themistius and the Imperial Court. Oratory, Civic Duty Paideia from Constantius to Theodosius. Ann Arbor, Mich.: University of Michgan Press. 


\section{CZY BÓG ZNA ZŁO? \\ ANTYCZNE ROZWIĄZANIE PROBLEMU \\ NA PRZYKŁADZIE FILOZOFII TEMISTIUSZA}

Streszczenie

Filozofia grecka, a w szczególności arystotelizm, ze względu na zawartą w niej koncepcję Boga nie podejmowała tematu Bożej wszechwiedzy, która wydawała się sprzeczna $z$ boską doskonałością, a co za tym idzie — również zagadnienie Boskiej wiedzy na temat zła nie było rozważane. W czasach Temistiusza, którego myśli tutaj przedstawiam, pojawiają się jednak nowe możliwości ukazania tego problemu pod wpływem nowej koncepcji Boga w neoplatonizmie i neoplatonizmie chrześcijańskim. Temistiusz, będąc świadom tych nowych zagadnień i włączając je do swoich rozważań, nie zmienił jednak schematu, w jakim powstaje jego stanowisko (arystotelizm). Zadał więc pytanie o to, czy Bóg zna zło, ale jego odpowiedź ograniczyła się w zasadzie do powtórzenia nauki Arystotelesa: Bóg poznaje samego siebie, tj. najdoskonalszy przedmiot poznania, a nie poznaje tego, co niedoskonałe, w tym braku, jakim jest zło.

\section{DOES GOD KNOW EVIL? \\ AN ANTIQUE SOLUTION TO THE PROBLEM ON THE EXAMPLE OF THEMISTIUS' PHILOSOPHY}

S u m m a r y

Greek philosophy, especially Aristotelianism, because of the concept of God present in this thought, did not raise the issue of divine omniscience and divine knowledge of evil. The divine omnisciene seemed to be contrary to God's perfect being. In the time of Themistius, whose thought I present in this paper, Neoplatonism and Christian Neoplatonism showed new possibilities of solving this problem. Themistius being aware of these new topics and including them in his own philosophy, still however represents ancient Aristotelianism with all its limitations. $\mathrm{He}$ asked about divine knowlegde of evil, but in his answer he repeated only the Aristotelian doctrine: God knows only Himself, because He Himself is the most perfect object of knowledge and cannot know less perfect beings.

Słowa kluczowe: Temistiusz; arystotelizm; Bóg; zło; Boża wszechwiedza.

Key words: Themistius; Aristotelianism; God; evil; divine omniscience.

Information about Author: Dr. hab. MONIKA KomSTA - Department of the History of Ancient and Medieval Philosophy, John Paul II Catholic University of Lublin; address for correspondence: Al. Racławickie 14, 20-950 Lublin; e mail: monika.komsta@kul.pl. ORCID: https://orcid.org/ 0000-0003-3070-3279. 